\title{
Capital gains, total returns and saving rates
}

\author{
Michael Hudson \\ University of Missouri, Kansas City, and Levy Economics Institute of Bard College, \\ Annandale-on-Hudson, NY, USA
}

To focus on the dynamics of how financial wealth is created, obtained, and valued, this paper (1) distinguishes capital gains from income by measuring total returns, and (2) contrasts the capitalized value of rentier income (rent extraction rights and privileges from land, natural resources, and monopolies) from that of industrial profits on tangible capital investment.

Keywords: national income accounting, saving, capital gains

JEL codes: $B 40, E 2$

\section{INTRODUCTION}

National statistics are not designed to show how fortunes are made in today's world. This should not surprise historians. Wealth always has sought to make itself invisible so as to avoid being taxed or regulated. Its aversion to statistical sunlight makes public policy blind (or at least, shortsighted) when it comes to measuring asset-price ('capital') gains or rentier income (economic rent and interest) in contrast to profits made by direct capital investment to increase output. Finance capital in particular prefers to hide its role in economic bubbles by depicting itself as part and parcel of industrial capital formation rather than as inflating asset prices.

Even for the economy's largest category, real estate, national statistics do not distinguish what portion of wealth comes from asset-price gains rather than new construction. Nor is it clear how much stock and bond market valuation stems from price gains rather than new issues and book value. The Federal Reserve's Balance Sheet of the Economy (Table $\mathrm{Z}$ in its Flow of Funds statistics) quantifies the overall value of US real estate, stocks, bonds, and savings, along with debt and net worth, but does not report assetprice gains separately from tangible capital formation.

What makes these distinctions so important is that since 1980 new investment has become much more debt-leveraged. Seeking capital gains rather than current income, investors have left their creditors with current income in the form of interest. To describe this phenomenon and trace its consequences, this paper outlines an accounting format to: measure 'total returns' by adding 'capital' gains to national income as reported in the national income and product accounts (NIPA), in Section 2; isolate economic rent (headed by land rent), interest, and other rentier income from profits on tangible capital formation; and based on these two measures, isolate asset values that stem from (a) capital gains and (b) rent-extracting activities, in Section 3; trace the rise in interest relative to taxes and net earnings so as to show the 'declining rate of profit' and fiscal squeeze that occur under financialization, in Section 4; and explain how debt-leveraged asset-price inflation gives way to debt deflation and negative equity, yet also a rising 'saving rate' as financialization 'crowds out' new spending and investment in the 'real' productionand-consumption economy, in Section 5. Section 6 provides a conclusion. 


\section{THE CHANGING COMPOSITION OF TOTAL RETURNS, FROM CURRENT INCOME TO CAPITAL GAINS}

Most of what has been applauded as wealth creation over the past generation consists of financialized 'capital' gains, not tangible capital accumulation. Most of these assetprice gains reflect debt leveraging at falling rates of interest and on looser credit terms.

This phenomenon is clearest in real estate. Even in the wake of the Industrial Revolution and post-industrial service society, it remains the economy's largest asset. It has been democratized on credit, obliging homeowners and commercial investors to pay out its rental value as interest in order to obtain the loans needed to buy it. So the rental income that empowered landed aristocracies in times past is now paid to financial rentiers. This means the post-industrial economy is now dominated by the Finance, Insurance, and Real Estate (FIRE) sector.

A key analytic problem is to impute how much of the rising property net worth comes from higher prices rather than from new construction. With regard to property prices, how much of the change reflects the land's site value relative to the cost of buildings? An analogous question applies to the stock and bond markets: how much of their net worth reflects rising price-earnings ratios as compared to new issues or retirements, and tangible capital investment? Also relevant are changes in property tax rates, because whatever the tax collector relinquishes is available for new buyers to pledge to the banks for the mortgages needed to buy the property.

Classical economics envisioned that land prices would rise as a result of population growth increasing the man-land ratio, as well as from higher prosperity and public investment in services that increase neighborhood site values. But the value of a property, stock, or bond is whatever a bank will lend against it. The loosening of bank credit therefore has played a key role. As the Federal Reserve drove down interest rates from their highs of 1980 (when the prime rate for US corporate borrowers was over 20 percent), bankers capitalized real estate, business, and personal income at rising multiples. This produced an accelerating debt-fueled bubble in bond, stock, and real estate prices, which increasingly diverged from the course of tangible capital formation.

Most of the growth in real estate asset value during this period reflects falling interest rates from their 1980-1981 highs to today's lows. Easing their credit terms, banks made interest-only loans that did not oblige borrowers to pay down the balance, leaving all their income to be used to pay interest. During the peak of the real estate bubble, borrowers did not even have to put down any money of their own as down-payments were lowered from the traditional 30 or 20 percent to zero by 2007. Bank mortgages thus were extended against the property's entire value, not just 70 or 80 percent of it.

To top matters, false valuations of borrowers' income ('liars' loans') and false appraisal values fueled the junk mortgage market. Under the 'light touch' bank regulation of Alan Greenspan in the United States and Gordon Brown in Britain, a rising wave of fraudulent appraisals and fictitious accounting practices spread after 2004, capped by the ability of banks to block financial regulation and even prosecution for financial fraud.

\subsection{Estimating the economy's total returns: net income + capital gains}

From the time of William Petty in the mid seventeenth century down through the 1960 s, a rental property was worth the discounted value of its revenue yield, on a par with government bonds (rentes in French). But looser lending terms raised the 


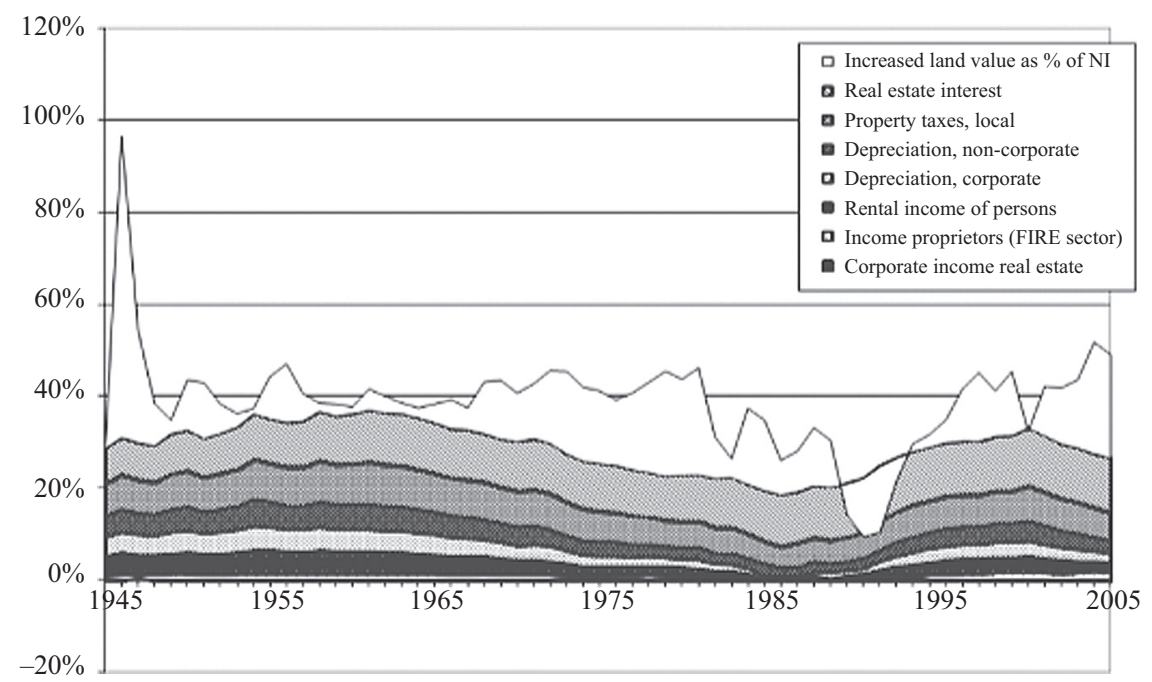

Figure 1 Real estate returns are achieved mainly by capital gains, not current rental income

capitalization ratio for real estate by more than rents were rising. It therefore paid investors to borrow, as long as the capital gains exceeded the interest charge. The larger this disparity grew, the more speculators engaged in debt leveraging. Prospective homeowners were panicked into buying before real estate prices soared yet further out of range. Many buyers even factored in the anticipated capital gain into their price bids (Figure 1). Banks encouraged owners to think of their homes as a 'bank account' to save and build up equity - or to borrow against the price rise by taking out 'equity loans' to spend on consumption.

By 2006, speculators were accounting for an estimated one-sixth of the residential real estate market. As new absentee owners sought renters to carry their carrying charges, rents drifted downward even as real estate prices rose, inverting the classical relationship between rental income and property prices from 2004-2008. In a market where everyone was scrambling to buy homes, few families wanted to rent when they could buy with nearly no money down, and join what seemed to be a financial free lunch.

This inverse relationship continued during 2009-2012: residential real estate prices plunged while rents rose as the number of renters increased. Home ownership rates retreated from 69.0 percent in September 2006 to 65.5 percent 6 years later, in September 2012 , showing the futility of trying to raise home ownership rates on credit terms that increase the share of housing costs to over 40 percent of wage income for many families (Figure 2). It was the banks that got rich.

For corporate and partnership real estate investors as well as home owners, the NIPA report debt service absorbing a rising share of the rental cash flow (Figure 3), as measured by EBITDA: earnings before interest, taxes, depreciation, and amortization. Debt-to-value ratios soared to over 60 percent for US real estate as a whole by early 2012, making banks virtual owners of residential real estate as creditor claimants. The capital gains that homeowners and many residential property speculators expected to provide total returns became net losses when property's declining net worth exceeded its income. 


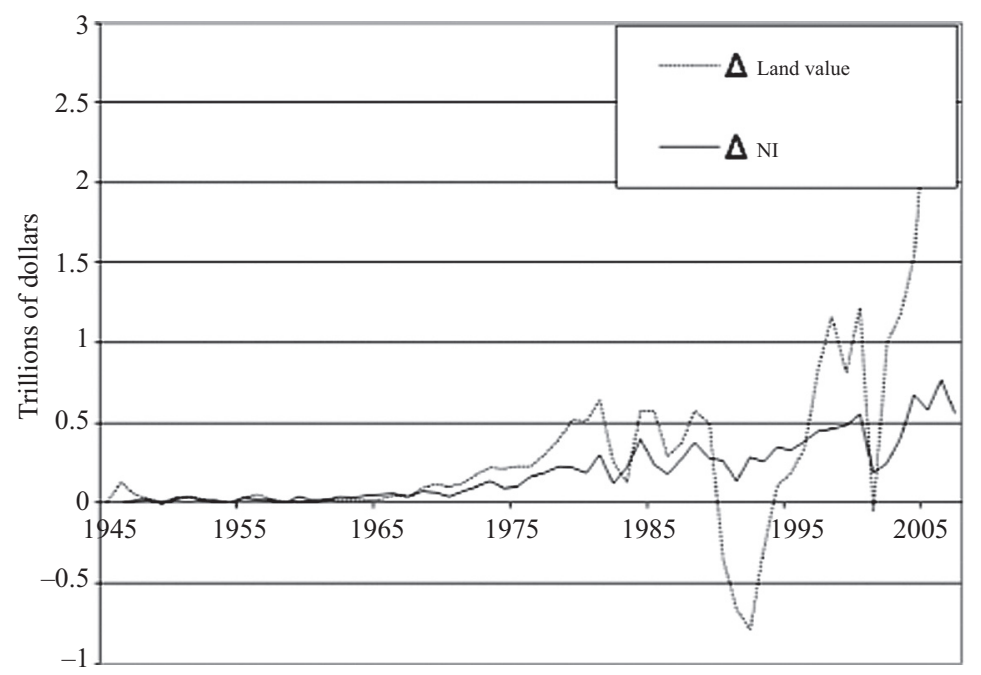

Figure 2 Land value gains (or losses) far exceed changes in national income

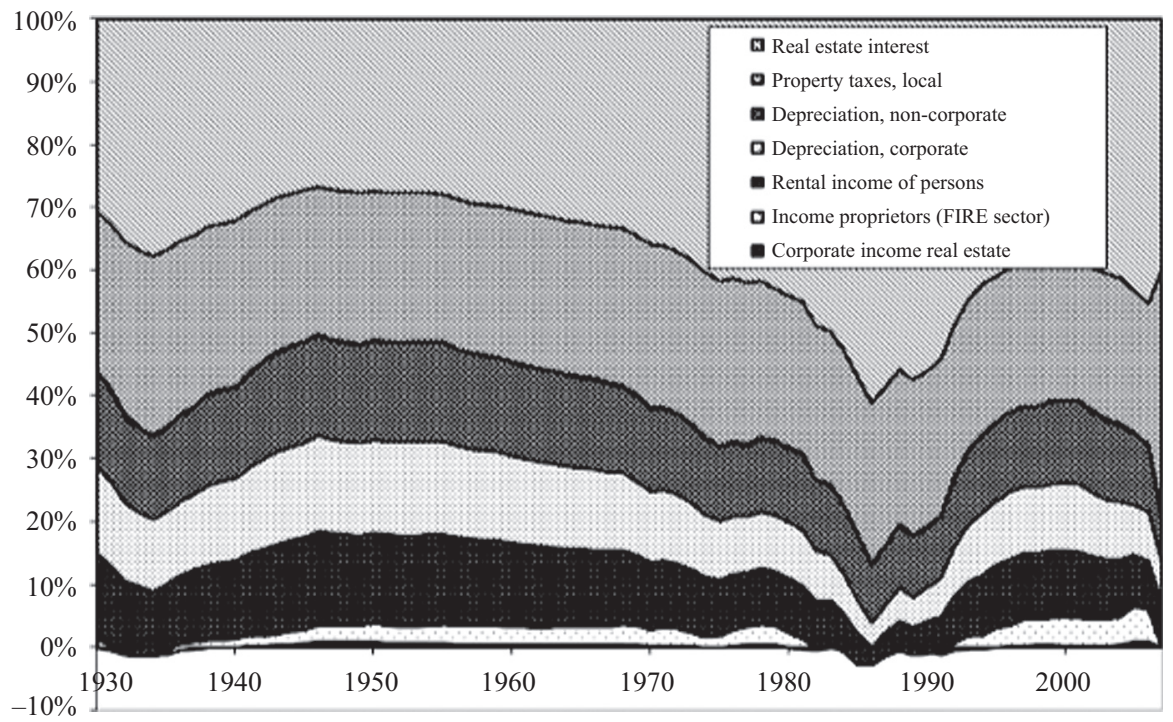

Figure 3 Net income falls while interest rises as a proportion of real estate EBITDA

\subsection{Conceptual problems in defining capital gains in real estate}

The Federal Reserve's balance-sheet statistics distinguish the value of land and buildings. But by treating land as a residual - after inflating the value of buildings by the annual construction price index - the Fed's methodology estimates land value far below what it otherwise would be. In fact, it makes land-price gains disappear to such an extent that in 1994 the Fed produced a negative \$4 billion estimated value for all the corporately owned land in the United States! 
Assigning the price rise to buildings runs counter to IRS depreciation practice that pretends that buildings are losing value even while overall property prices are soaring. My own estimates show that US land valuation should be doubled, reducing building estimates by a similar amount. Adding the land's imputed price gain to the NIPA's estimate of real estate EBITDA to derive a measure of total returns to the real estate sector (Figure 2) shows how far land-price gains (or since 2008, price losses) exceed reported earnings and cash flow. Capital gains were the main source of new "wealth creation' during the 1990s and 2000s.

\subsection{Policy conclusion}

This explains why real estate investors have aimed mainly for capital gains since the end of World War II. For the past generation, capital gains have out-paced all other forms of economic surplus. Investors have ridden the wave of asset-price inflation, and have translated their gains into the political power to cut taxes on this dynamic, distorting industrial economies to favor speculation. It is a distortion because it is much easier to aim for such gains than to invest in tangible capital formation. It is easier to buy an industrial company and extract financial gains than to undertake new direct capital investment and develop new markets.

Classical economics viewed the economic surplus as taking the form of profits on tangible capital, rents on land, natural resources and monopolies, and wages over and above basic subsistence levels. Savings and wealth were assumed to be accumulated out of these surpluses. From the Physiocrats through Adam Smith, John Stuart Mill, and the Progressive Era, classical reformers sought to tax resource rents, which they viewed - along with interest on financial capital - as being paid out of this surplus.

Classical economists would have treated most (but not all) of this revenue as a subtrahend from output. Frederick Soddy characterized financial claims and other rentier claims for payment as 'virtual wealth': an asset to creditors (or rent extractors), but a debt to their clients. Today's NIPA reflect the post-classical counter-revolution by treating all rentier income as 'earnings,' including that of the FIRE sector, which 'earns' this income for providing a 'service,' ipso facto.

Capital gains are the result of lower taxes as well as lower interest rates. The early US income tax treated these gains as normal income, on the logic that they added to net worth just as did income. But as financial and real estate lobbyists gained increasing tax favoritism, subsequent fiscal policy taxed asset-price gains at only about half the rate charged on normal income. The 'Reagan Revolution' of 1980 made real estate investment revenue almost entirely exempt from income taxation, while further lowering taxes on capital gains.

This tax shift has left more rental cash flow available to pay bankers as interest. Reversing this shift by taxing the land's 'unearned increment' (the rise in site valuation) would leave less rental value to be capitalized into bank loans (thereby lowering real estate prices), while enabling government to avoid taxing labor, capital, or retail sales (thereby lowering the break-even cost of employment as well as consumer prices).

\section{FIRE-SECTOR REVENUE CONTRASTED WITH NON-RENTIER EARNINGS}

Distinguishing cost value from market price enabled classical economists to contrast profits and wages with 'unearned' economic rent. Their aim was to contrast wealth accumulated from industrial capital formation (whose cost ultimately was reduced to 
that of labor) from property rights and privileges (economic rents) whose income has no counterpart in technologically or economically necessary costs of production. Economies become more competitive by investing in productive capital formation while minimizing extractive 'virtual wealth' in the form of property rights to receive rent or creditor claims to receive interest. Such rentier income is merely a transfer payment, siphoning off revenue from the economy at large rather than being necessary for production to occur. In this view, economies should tax away rentier income or socialize the relevant functions into the public sector to provide on a less exploitative basis.

Landowners, monopolists, and their financial backers preferred the approach of J.B. Clark in the United States and contemporary late nineteenth-century marginalists who treated all income as being earned, by definition, for providing a service. Rents were rationalized as being paid for providing landlord services, natural resource rents for organizing mines and forests to produce income, and interest to bankers and bondholders for providing credit and other financial services. ${ }^{1}$

This is the logic that today's NIPA adopt by treating all forms of income as 'earnings' that have a counterpart in 'product.' The concept of economic rent as unearned income does not appear, leaving no basis for distinguishing between real estate income stemming from land rent - or monopoly gains at the expense of the non-rentier 'real' economy - as compared to the return on capital invested in buildings and other improvements. So there is no means to isolate asset valuations for real estate or monopolies that capitalize revenue from rent extraction.

\subsection{The FIRE sector as the economy's largest and most paradigmatic rentier sector}

The NIPA usually have grouped real estate and financial activities together, for example mortgage brokerage, assessing, and property insurance. This relationship grew even closer after Glass-Steagall was repealed in 1999, permitting financial conglomerates to extend into real estate and insurance, starting with Citibank's precipitous merger with Travelers. Mortgage-lending accounts for some 80 percent of bank loans in the United States, most other English-speaking countries, and Scandinavia, making real estate by far the largest bank client. This makes focusing on the FIRE sector the simplest starting point to estimate rentier income from existing statistics.

Given the present accounting format, this is as far as one practically can go, because the FIRE sector does not include economic rents from mining, oil and gas, other natural resources (forests and fisheries), or the broadcasting spectrum and its bandwidth frequencies. Nor does it include monopoly rent from intellectual property rights, natural monopolies such as toll roads, or financialized public utilities. In theory these rentier functions could be broken out as a layer of the economy alongside the FIRE sector. Breaking out this sector shows:

1. The rising role of rentier income and capital gains relative to wages and profits on capital.

2. The rising proportion of real estate cash flow paid as interest to the financial sector (rather than to the tax collector as envisioned by most classical economists), reflecting

1. I deal with J.B. Clark's approach in Hudson (2011). 
3. The rising proportion of real estate value represented by debt leveraging. Bank mortgages now account for nearly 60 percent of residential real estate value in the United States. In 2008, US homeowners' equity plunged below 50 percent for the first time on record.

4. The rising proportion of asset values from capitalizing rent-extraction privileges on credit rather than commodity price inflation. Wages and other prices remained fairly stable while property prices, stock, and bond markets boomed as a result of bank credit expansion.

In contrast to the era of direct land ownership, property is now bought on credit. The guiding principle of real estate investors is still 'Rent is for paying interest.' (And for two-thirds of the US population, wages are largely for paying interest on buying a home.) Buyers bid for real estate loans, with the winner often willing to pay the entire rent or use value to the banker, hoping to emerge with a capital gain as property prices rise. As long as asset-price inflation is expected to continue, interest rises as a proportion of real estate EBITDA.

This has become the distinguishing feature of bubble economies: instead of wealth being saved up out of profits on capital investment or out of wages, it takes the form of rising asset values relative to the rise in debt - until the phase of debt deflation takes over and pushes debt-leveraged assets and investments into negative equity.

\subsection{Policy conclusion}

Most tax systems favor rentier income and capital gains over profits and wages. US real estate investors are allowed to pretend that their buildings are losing value, for which they receive a 'depreciation' credit set high enough to render rental property exempt from having to pay income tax. New buyers are permitted to start depreciating buildings afresh each time they change hands. The same building can be depreciated again and again, at a higher depreciation base each time land and property prices rise. No capital gains tax needs to be paid if the seller reinvests the gain to buy yet more property.

The fiction at work is that buildings lose value. The reality is that landlords typically spend about 10 percent of rental income on maintenance and repairs. Indeed, local tenant protection laws typically require maintenance. The Federal Reserve's flow-offund statistics use a construction price index to impute how much building values increase each year. But as noted above, while this assumption helps justify depreciation at rising price estimates, it creates another economic fiction by underestimating the land's residual site value.

By indulging in these accounting fictions, national statistics support tax policies favoring real estate. The effect is to leave more revenue to be paid to the banks. Freeing land and other rentier assets from taxation reverses classical doctrine that sought to make economic rent the tax base. Untaxing land leaves rental income and capital gains to be capitalized into larger bank loans, raising housing prices as well as obliging cities, states and the federal government to make up the shift by imposing income and sales taxes on business and labor.

The classical aim was to tax away prices over and above value. Taxing the rent attributable to land (as distinct from tangible capital improvements) has two effects. First, it prevents this revenue from being available to capitalize into bank loans. Assuming the land's site value to represent about half the typical property's cost, taxing ground rent would cut mortgage loans - and hence, property prices - roughly in half. It also would enable state and local governments to avoid taxing income or sales. 
This would minimize the cost of living and hence of employing labor. It therefore would make economies more competitive by bringing prices in line with cost-value - the intrinsic costs of production - instead of letting them be swollen by rentier charges diverting income from being spent in the 'real' economy.

\section{FINANCIALIZATION, THE FALLING RATE OF PROFIT, AND THE TIME FRAME OF PRODUCTION}

The concept of depreciation (the return of capital to investors) was added to classical value theory and national income analysis by none other than Karl Marx (Hudson 2010; Marx 1952). His critique of Quesnay's Tableau Économique pointed out that investors needed to recover their original investment as well as make profits on this investment. As production became more capital-intensive - and as machinery obsolesced more rapidly as technological innovation raised capital productivity - it followed that depreciation and amortization of capital equipment would increase relative to profit as a proportion of EBITDA. This 'falling rate of profit' was in-keeping with the belief that industry (as well as agriculture and other spheres of production) would become more capital-intensive - or 'roundabout' in Eugen von Böhm-Bawerk's terminology. To the Austrians, interest and profits were payments rewarding savers and investors for their 'patience' in preferring more returns at a later point of time as production periods lengthened.

However, recent trends have not been more capital-intensive or reflected long-term patience. Information technology, inventory control systems and schlocky building practices have been 'capital-saving,' reducing the role of depreciation (except in real estate as noted above, where new buyers can depreciate buildings repeatedly at higher valuations). To cap matters, as economies have become more financialized, the business time frame has become more short-term, stripping assets by using depreciation credit and even borrowing to pay bondholders and stockholders, or simply for stock buy-backs to create capital gains. What has increased as a proportion of cash flow 'crowding out' profit is interest and related debt service. The 'magic of compound interest' tends inexorably to expand the debt overhead.

This debt leveraging and related financial short-termism of the US, British, and other highly debt-leveraged economies did not deter the build-up of fortunes as long as falling profits and rising indebtedness were more than offset by capital gains fueled by easy credit. But rising debt-income ratios divert wages and profits to pay creditors, leading ultimately to debt deflation. Markets shrink, limiting sales and profit opportunities.

Rates of return on real estate have been revived since 2008 by de-leveraging. All-cash purchases by hedge funds and real estate investment trusts (REITs) have accounted for a reported one-third of the market, mainly to buy rental properties seeking the rental income formerly paid to mortgage bankers as interest. While their purchases have created a 'bounce' of capital gains, de-financialization has reversed the falling rate of profit - at least while the new institutional buyers package and sell their revenue streams into new bondholders.

\section{SAVING RATES IN FINANCIALIZED ECONOMIES}

The US saving rate declined to zero by the time the bubble economy peaked in 2008 . Netting out foreign investment in US securities left the domestic saving rate at a negative 2 percent of national income. Despite the outcry about national profligacy, most 
investors (and homeowners) felt that they were growing richer. Asset prices were rising more rapidly than debt was growing, producing Total Returns entirely by capital gains. This debt leveraging and its cannibalization of net revenue by the financial sector is a characteristic of economic bubbles.

The disconnect between the national income concept of saving and balance-sheet capital gains (or after 2008, losses) has marked the post-bubble downturn as well, but in reverse. Banks extended little new mortgage credit after 2008, but received amortization pay-downs. The net US saving rate turned positive, to 3 percent. However, this saving has not taken the form of money in the bank or new tangible capital formation. It simply reflects debt repayment - a financial 'negation of a negation' counted as positive. ${ }^{2}$

About a third of the net US debt reduction is the result of writedowns, not actual repayment. This is not 'saving,' but the Internal Revenue Service treats it as taxable income for beneficiaries of debt writedowns. The logic is that if it improves their balance sheet, it is income. But this principle is not applied to recipients of capital gains, which are taxed at a lower rate!

To explain this asymmetry, it helps to view our economy as being multi-layered, with the wealthiest 1 percent acting as a creditor class holding the non-financial population in debt. This dynamic can be described only by grounding economic analysis in the balance sheet of wealth and debt to see who benefited most and who ended up owing most as 'total returns' were inflated before 2008, and subsequently deflated as the bubble economy gave way to debt deflation. Integrating balance-sheet analysis with the NIPA shows that the economy normally performs either much better or much worse than is reflected in GDP and the NIPA alone.

\section{CONCLUSION: WEALTH VERSUS OVERHEAD}

Classical economists sought to free industrial capitalism from the legacy of feudalism, above all from the rentier privileges of privatized land rent, natural resource rent, monopoly rent, and financial charges. As policy reformers, their value and price doctrine sought to guide economies to minimize 'price without value,' treating rentier revenue as an overhead, not as having a counterpart in 'service' product. The public sector was to collect the land's site value and natural resource rents, which it would use to pay for transportation, schools and other public services. Rather than extracting rent, governments would provide these public services at cost, on a subsidized basis, or freely and hence 'out of the market.'

Under this scenario all profits would indeed be 'earnings' for actually providing services. In this sense, socialism aimed at making economies more competitive as well as more fair. Lower costs of living and doing business would mean lower labor costs, and hence lower prices for the products that labor makes. The aim was to free economies from unearned income.

What is ironic is that, as currently structured, the NIPA would apply most appropriately to a socialist economy in which this policy aim has been achieved! The NIPA accounting format depicts the world that classical economists envisioned: an economy that has freed itself from economic rent in private hands.

This aim was rejected, along with the progressive tax policy it advocated, as economic theory was turned largely into a lobbying effort to rationalize rentier privileges

2. I discuss the details in Hudson (2006). 
and gains. Instead of finance being industrialized, industry was financialized. Most wealth in today's economies continues to be rentier savings and legal privileges. Bankers and bondholders have replaced landlords as the main recipients of economic rent, extracting it in the form of interest paid by the real estate, natural resources, and monopolies - rental revenue that classical economists hoped to make the tax base.

This flow of interest has been re-lent, along with new bank credit, to fuel an exponential debt-financed purchase of assets. This makes it easier to make gains by debt leveraging and riding the wave of asset-price inflation - and by putting up rentextracting tollbooths at key access points for basic services and monopolies - than to invest in new production. A realistic set of national accounts should quantify and pinpoint this dynamic, and provide a format to trace how economic rent that is not taxed becomes 'free' for banks to capitalize into loans.

Banks find it easier to lend against real estate already in place, and stocks and bonds already issued, than to estimate the viability of loans to finance new means of production. (New construction and film financing are fortunate exceptions.) They find willing borrowers as long as investors expect asset prices to rise above the interest charge. The result is that credit is extended mainly to load the economy's assets down with debt while bidding up asset prices. Balance-sheet gains and losses thus need to be added to the NIPA to explain why financial bubbles accelerate while paving the way for subsequent debt deflation - in which saving rates 'recover.'

\section{REFERENCES}

Hudson, M. (2006): Saving, asset-price inflation, and debt-induced deflation, in: Wray, L. Randall, Forstater, Matthew (eds), Money, Financial Instability and Stabilization Policy, Cheltenham, UK and Northampton, MA, USA: Edward Elgar, 104-124, reprinted in The Bubble and Beyond: Fictitious Capital, Debt Deflation and Global Crisis (ISLET, 2012).

Hudson, M. (2010): Marx to Goldman Sachs: the fictions of fictitious capital, and the financialization of industry, in: Critique 53, 38(3), 419-444.

Hudson, M. (2011): Simon Patten on public infrastructure and economic rent capture, American Journal of Economics and Sociology, 70(4), 874-903.

Marx, K. (1952): History of Economic Doctrines, edited and translated by Terence McCarthy, New York: Langland Press, introduction. 